\title{
Activity at work, innovation and sustainable development
}

\author{
Béguin, P., ${ }^{\mathrm{a},}$, Duarte, F. ${ }^{\mathrm{b}}, \mathrm{Lima}^{\mathrm{c}}$ F. and Pueyo, $\mathrm{V}^{\mathrm{d}}$ \\ ${ }^{a}$ Département Sciences pour L'action et le Développement (SAD-APT) - INRA, 16 rue Claude Bernard, \\ 75321 - Paris cedex 05 - France \\ ${ }^{b}$ Production Engineering Program - COPPE/UFRJ - Federal University of Rio de Janeiro, BP 68507, \\ CEP 21945-970 Rio de Janeiro - Brazil \\ ${ }^{c}$ Production Engineering Deparment - UFMG - Federal University of Minas Gerais - Belo Horizonte Minas \\ Gerais \\ 'Institut d'Etudes du Travail de Lyon, 86 rue Pasteur 69007 Lyon - France
}

\begin{abstract}
The aim of this paper is to present and discuss a French-Brazilian project (CAPES-COFECUB) centered on the relations between sustainable development, innovation and changes in work activities that accompany these innovations for sustainable development. Sustainable development calls for an integrated approach of three dimensions: social equity, economic viability and environmental sustainability. In order to achieve this integration, considerable innovations efforts are required. However, the work, understood as a productive act, is deeply lacking in the current researches. Starting from the idea that work is a "fundamental need" the goal of this project is to propose innovative methods that can be used for designing production systems from the perspective of sustainable development.
\end{abstract}

Keywords: work, innovation and sustainable development

\section{Introduction}

The research project work, innovation and development was established by Brazilian and French Universities and Research Centers and began in 2011. The main objective is to contribute, conceptually and methodologically, to the development of strategies for designing work systems that facilitate innovation from the perspective of sustainable development.

Sustainable development calls for an integrated approach of three dimensions: social equity, economic viability and environmental sustainability. To articulate these three "pillars" we must focus on the one hand on innovation and technological choices, and on the other hand on policy and normative dimensions at different scales [18]. So, from a technological point of view, sustainable development requires significant innovative product, but there's also the need to better articulate specific local sociotechnical dynamics and politics issues related to sus- tainability during the design process specific [22]. However, work activity is not sufficiently reflected in the innovative efforts that accompany sustainable development.

Work (whether paid or not) should be considered as a "fundamental need" for all populations. Two arguments can be made on this point. Firstly, work produces fundamental goods, but can, at the same time, lead to environmental degradation. Secondly, work can be positive on health but can also lead to deterioration (physical and/or cognitive).

For several years, innovation strategies taking into account activity at work have been object of research in ergonomics [7]. The most recent work led to constructivist design approach, focusing on mutual learning between operators and designers, taking to take into account human variable of innovations and particularly "configurations" specific to a given environment, which will already have its own particular history, criteria or values [8].

\footnotetext{
*Corresponding author. E-mail: pbeguin@grignon.inra.freditorial@iospress.nl.
} 
In this project, the aim is to go one step further. The main idea is to better articulate the normative dimensions of politics and technical design, integrating as early as possible to the project's process, questions related to changes at work in the long-term.

\section{The three pillars of sustainable development - SD}

The themes and challenges of SD stem from a history of thinking about social and economic development, and have its origin in a criticism of the view of understanding development exclusively as economic growth [28]. Since the 1960s, questions have emerged about the social and institutional changes required in addition to the growth of production and profit - including issues of education, human capital and sanitation policies. Another emerging question, since then, is related to the real possibilities of market mechanisms to satisfy the dimensions relative to social equity. At the same time, a new set of questions emerged regarding ecological concerns in a global economic context. The term "sustainable development" (SD) appeared within this context, and was developed further in the Brundtland report [10]. SD is characterized by three pillars:

- Social Equity: refers to the idea of fundamental needs and autonomy. The main goal of development should be to meet the fundamental needs (material and immaterial) of the most needy populations. To do this, the autonomy of individuals and populations must be fostered. With this perspective, the United Nations Development Programme (UNPD) reports that "Human development is about much more than the rise or fall of national incomes. It is about creating an environment in which people can develop their full potential and lead productive, creative lives in accord with their needs and interests." (www.undp.org).

- Environmental sustainability: Since the 1970s, Milton and Farvar [24] have reported on the very negative consequences of economic development on the environment (resources, biotype, soil, biodiversisdade) in southern countries. Yet very quickly pressure on ecosystems was at a global level. This pressure was enhanced with the awareness of climate and energy crisis. This gave rise to the question of preservation and crea- tion of natural resources.

- Economic viability: in a world where economic and social needs are present, an approach focused exclusively on nature would be axiologically untenable and politically unrealistic. Therefore, the protection of the environment must be considered within a more global development strategies context.

\subsection{Sustainable development: technical and political aspects}

The central question and challenge of SD seems to be the relation between economic processes and the transformation of the environment and the resources it uses. These relationships are doubly mediated: by technology, that forms the link between the social and physical world, and by concerns of sustainability, both in terms of social equity and the environmental variable:

- The possibilities for developing innovative technologies is a key variable for the harmonization of the different goals pursued by societies. Technology is in fact a great locus for the articulation between societies and nature. The goal is therefore to adapt techniques to the natural and social characteristics of different regions of the world - issues dealt by the appropriate technology - and aspirations of the population, rather than adapting the environment and the population to the techniques devised for the developed West. This does not mean that the contributions of modern science should be excluded, but it requires that technological applications be developed considering the precise context of their introduction.

- The theme of environmental and social sustainability adds yet another dimension. Development which benefits human needs and modern societies cannot lead to degradation of the biophysical environment and should preserve future generations. The term SD was coined to affirm this new dimension of sustainability. Considering the aspirations of the population is therefore necessary but not sufficient to guarantee SD, since resources are limited.

Consequently, SD articulates on the one hand, descriptive and analytical categories mobilized by innovative technology and on the other, normative and political categories. This integration implies better 
articulation between technical and public action. In this sense, the issue of collective action is present even in design processes.

\subsection{Technological innovation: product and process}

Faced with the challenge of SD, innovating is indispensable for different economic sectors, from agricultural production to the most advanced technologies for energy production. This is true both in terms of having innovative products and in regards to making use of processes which are less harmful to the environment (or that make use of recycling, ...).

Thus, innovation in the context of SD does not refer solely on the development of products. It also implies an evolution of the processes. So in fact, talking about innovation does not mean simply designing a new product, but also to situate the emergence of this innovation within the interaction between, on one hand, the work carried out in research centers and project offices and on the other, the receiving environment [31]. This articulation between technical innovations and the environment leads to an upgrading of design approaches. It is within this perspective that, for example, Masson et al. [22] distinguish two design approaches. The first, which is inappropriate for innovation, is what we'll call "controlled design". This strategy is characterized by the fact that its criteria for success is stabilized, the specialties involved are identified and all the procedures are known. However this strategy is inappropriate for innovation, as knowledge evolves according to the singularities of the environment and the local dynamics. Two dimensions identified in the literature seem essential in the context of SD:

- The first dimension is to better address local socio-technical dynamics typical of the receiving environment. Several works $[1,16$, $20,23,27,32]$ have shown that a technique influences and potentially configures the environment which admits it. But these studies also show that new techniques are always set in motion and transformed during its dissemination and appropriation by the receiving environment. From this point of view, what's important is to better address the human variable of innovation and the historical, social, cognitive structures of a given environment, which will always have its own, particular history and set of criteria.

- The second dimension aims to respond to the need of expanding design criteria to be- yond economic dimensions. The works that examined innovation from the perspective of the relation between science-society have made it clear that scientific and technical knowledge can introduce many uncertainties. Some examples of this are the risks that today characterize our society, such as that of the nuclear industry for example [3], and also the great global challenges (ecological, energetic).

The first dimension leads to the understanding of design as an emergent process of self-organization, rather than a linear process for reducing uncertainty, as argued by traditional project models. The second dimension leads to treating scientific dynamics as relative and accepting non-scientific dynamics as legitimate, as designated by the term "third sector of science." This question is not absent from debates about technology [17]. However, there is still not enough emphasis of normative politics dimensions in the design process.

Hence, for SD, the aim of innovation is to integrate the socio-technical dynamics of the receiving environment and sustainability issues into the design process. However, human labor is still not sufficiently taken into account in the innovation efforts of SD.

\section{Considering work in innovation}

In this project, work is seen as a finalized activity, whether paid or not, producing objects or values, done individually and / or collectively by a man or a woman in a given time frame, situated in a particular context that fixes the restrictions of the situation. This activity is not neutral; it engages and transforms the person performing it.

This consideration of work is not entirely absent from the discussions that led to the notion of SD. In fact, from the 1970s onwards, the emerging development activities in southern countries had very negative consequences on the environment - natural resources, biotypes, soil, biodiversity, etc. - due to a combination of different factors: inadequacy of Western technologies and little knowledge of objectives, priorities and cultural references of local populations etc., which led to worrying degradation [24]. This degradation itself has become an obstacle to improving situation and living conditions of poorer populations, who earn their livelihood from natural resources. Likewise, the issue of technology transfer 
brings up a series of questions that show that not considering cognitive conditions [26] and also the social dynamics of the recipient countries can lead to work situations which are not only costly to individuals but are also very dangerous (see, for example, an analysis of the Bhopal accident [34]).

\subsection{Work, a fundamental need}

Yet the question of work seems to lose ground to the issue of environmental sustainability. There are research orientations in which the energy balance of the food consumed by populations is compared with the efficiency of agricultural production systems. In reality, for a sustainable agriculture, it is also necessary to think about the working conditions of farmers. As mentioned before, work can be considered a fundamental need or asset. Two arguments support this position.

The first refers to the fact that work produces goods (material and immaterial) on a territorial scale. We have seen that social equity is related to the right of the population to meet their fundamental needs. We can continue Sen's analysis [30] on the notion of capability. Faced with similar goods, different populations do not have the same opportunities to live a wholesome life. In this sense, work is a capability that allows one to have a healthy life, as it produces material goods (local infrastructure, subsistent or income-based agricultural production etc.) and immaterial goods (skills, for example) at a territorial scale. Work is in itself a legitimate project.

The second shows work as a factor for well-being under two conditions: if it does not bring risks to vital capacities and if it allows workers to find new opportunities for development. This is what is emphasized in research on the relationship between work and health [11]. A series of studies have shown that work is a resource for workers. Simultaneously, the major economic and management strategies, social choices for work organization and techniques used can lead to exclusions and health risks, with heavy consequences for both workers and populations [25]. In this sense, one may recall the recent estimates of the French Ministry of Labor [19]. The overall cost for occupational accidents and diseases is estimated at between $2.6 \%$ and $3.4 \%$ of GDP, or the equivalent of about 10 vacation days in the calendar year.

\subsection{Work systems design: the activity-centered ergonomics approach}

From the 1980s onwards, the theme of design has been central to ergonomics, both in research and teaching. Two questions were immediately raised which led to ergonomics being introduced to the design process: (i) how is it possible to build knowledge about the consequences of work activity and project choices during the design process, both in terms of performance and comfort? and (ii) how is it possible to innovate when the analysis of existing activity can lead to a certain inertia? To answer these questions, several ergonomics approaches were developed [6, $13,16]$.

The oldest approach stems from the idea that any technical device, every artifact, crystallizes knowledge, a representation and, more broadly, a model of the user and his activity. Once crystallized in the artifact, these models are conveyed in work situations, and if they false or insufficient can cause difficult for people. With this in mind, it is essential to develop models for users and their activity and make them available to designers, or even do experiments or simulations using these models. A user activity model is therefore a source of inspiration and a feature for the activity of designers. With this perspective, ergonomics has developed work analysis methods (analysis of situations to transform or analysis of reference situations), with the aim of using it for design.

However, from the 90s onwards, this approach was considered insufficient in ergonomics. In fact, the anticipations made during the design process cannot entirely determine the action. Therefore, the human activity is not a simple execution, but rather an ability to adapt to circumstances and to act at the right time. Hence the following principle: it is necessary to develop systems which are flexible and elastic enough, leaving place for the activity to make the technique more efficient, both in terms of productive efficiency and in terms of consequences on people. This perspective was, for example, developed by Daniellou [12] with the notion of "possible future activity": the ergonomist seeks to build a "space within in which the activity can be developed". This same point of view was most recently searched by Vincente [33], with the idea of defining "envelopes for use" (whenever the need to limit adaptability arises, especially for security reasons). In these approaches, the goal is not to specify technical solutions, but rather to specify a set of resources for the action. This theme is now being explored in research on agriculture [14]. 
From the late 90 s, a question arose regarding development. Indeed, a plasticity-based approach rests primarily on a homeostatic model of work activity: the worker develops strategies to meet situational contingencies or variability of his own internal state. Now the theme of development postulates that the operators' strategies happen inside their frame of thought and action, which are in turn determined by technologies, as well as the conditions and changing necessities of environments and populations [21] (Laville, Gaudart, \& Pueyo, 2004). This perspective led to constructivist approaches, where the central idea is to reintroduce the activity's development into the design process, rather than just develop artifacts $[5,16]$. Indeed, in design offices, tools and procedures are developed. These are artifacts. Yet, this leaves little place for the development of activities and for learning. Therefore, the development of situations both in term of the organizational and material components - and the development of activities should be considered jointly during the design process. The difficulty is to articulate all at once, the specification of artifacts by the designers and development of the activity by the operators.

One of the basic methodological principles of this approach lies in the fact that design is a cyclical process. Shön [29] has highlighted this aspect with the famous metaphor of a dialogue with the situation: the designer, with the end goal in mind, designs ideas and knowledge, but the situation responds. It presents unexpected resistance that prompts the designer to learn. So what is sought is to introduce the recipients of technological innovation to the design cycle: aiming to be objective about the possible or impossible learning that will occur during work activity and based on this, organize the designers' learning [15]. Design appears as an emergent, interactive process, with designers and operators learning mutually from each other [4]. The objective of design evolves to the same extent as the dynamics in the exchange between operators and designers do.

Such dynamics allows a more careful consideration of the innovations' human variability and of the structure (historical, social) of a given environment, which always have its own, particular set of criteria, history or standards [8]. In this sense, we believe that ergonomics can contribute to innovation in SD.

\section{Expected results}

Through this French-Brazilian project, we hope to go one step further. The central idea is to better articulate (i) the normative dimensions of politics in the context of sustainable development, and (ii) engineering needs and practices for design by incorporating as soon as possible to the design process the questions relating to changes in long-term activity at work. In accordance with this aim, three scientific issues will be pursued during the project.

- To give greater emphasis to collective action and participatory processes within the design process. Sustainable development involves linking descriptive and analytical categories mobilized during design and categories of politics and norms. This raises the question of "common worlds" (in the sense proposed by Arendt [2], i.e. the articulation between what is shared in a community, and what is specific to everybody), and the role they can play within the design process.

- Designing socio-technical systems which contribute to the development of capabilities. The main idea is to design socio-technical systems which provide the possibilities for people to develop their capacities beyond the temporal boundaries of one project, and provide the ability to manage their own development in the future [16]. Our main idea is that the product, but also the design process in itself (including in its formative dimension) can contribute to grasp such an objective.

- Specify "boundary objects" for designing. Works in ergonomics have led to the proposal of "boundary objects" suited to the design of work systems (volumetric model, full scale models, prototypes, etc) [9]. However, innovation for sustainable development involves extending the unit of analysis beyond the work system. We must design work setting in an ecological system and larger social scale of a territory or industrial area. A third outcome of the project is therefore to better characterize "media" and "tools" which could contribute to and support the design process of work systems in order to facilitate innovation in the context of sustainable development. 


\section{References}

[1] Akrich, M. 1993. Les objets techniques et leurs utilisateurs, de la conception à l'action, Raisons Pratiques, $n^{\circ} 4$, « les objets dans l'action $», 35-57$.

[2] Arendt, H. (1983/1961). Condition de l'Homme moderne. Paris : Calmann-Levy, Coll. Agora Newman and E.T. Liu, Perspective on BRCA1, Breast Disease 10 (1998), 3-10.

[3] Beck, U (1986). Risikogesellschaft, Francfort, Suhrkamp Verlag

[4] Béguin, P. (2003). Design as a mutual learning process between users and designers. Interacting with Computers. 15/5, 709-730

[5] Béguin, P. (2004). L'ergonomie en conception. Les nouveaux régimes de la conception, A. Hatchuel \& B. Weill, Juin 2004, Cerisy-la-salle

[6] Béguin, P. (2007). Taking activity into account during the design process. @ctivités, 4 (2), pp. 115-121, http://www.activites.org/v4n2/v4n2.pdf.

[7] Béguin, P. (2010). Conduite de projet et fabrication collective du travail : une approche développementale. Habilitation à Diriger des Recherches. Université Victor Segalen, Bordeaux 2.

[8] Béguin, P., Duarte, C. (2008). A inovacão: entre trabalho dos projetistas e o trabalho dos operadores. Dossier Temático. Laboreal. Vol. 4/2, p 10-14

[9] Broberg, O. (2008). Quando o projeto participativo de espaços de trabalho se encontra com o projeto de engenharia em eventos de colaboração mútua. Dossier Temático: A inovação: entre o trabalho dos projetistas e o trabalho dos operadores, P. Béguin \& C.Duarte. Laboreal, Vol. 4/2, pp 50-

[10] Whited Nations World Commission on Environment and Development (1987), Our Common Future: The Brundtland Report, Oxford, Oxford University Press

[11]Clot, Y., Litim, M., Lhuilier, D., Béguin, P., Falzon, P. (2009). Santé / Travail : la recherche en Ile de France. Inventaire, répertoire et perspectives. Rapport de mission pour l'Agence Nationale de la Recherche. Document du Centre de Recherche Travail et Développement, CNAM Paris.

[12] Daniellou, F. (2004) L'ergonomie dans la conduite de projets de conception de systèmes de travail. In P. Falzon (Ed.) Ergonomie. Paris : PUF.

[13]Daniellou, F. \& Béguin, P. (2004) Méthodologie de l'action ergonomique : approches du travail réel. In P. Falzon (Ed.) Ergonomie. Paris : PUF

[14]Dedieu B., Chia, E.., Leclerc, B., Moulin, C.H., Tichit, M. (2008). L'élevage en mouvement - Flexibilité et adaptation des exploitations d'herbivores. Quae éditions, Paris.

[15] Duarte, F., Conceição C., Cordeiro C., Lima, F. (2008). A integração das necessidades de usuários e projetistas como fonte de inovação para o projeto. Laboreal. Volume 4/2, pp 62-74.

[16] Falzon, P. (2005). Ergonomie, conception et développement. Conférence introductive, 40ème Congrès de la SELF, SaintDenis, La Réunion, 21-23 septembre 2005.

[17]Feenberg, A. (1999). Questioning technology. Routledge, Londres.

[18] Gaudard, O., Hubert, B. (2002). Le DD et la recherche scientifique à l'INRA. Rapport à Mme la Directrice générale de l'INRA. Rapport intermédiaire. 58 pages

[19] Larcher, G. (2004). Discours de clôture du $7^{\circ}$ Forum international travail santé, www.travail.gouv.fr

[20]Latour B. et Woolgar S. (1979). Laboratory Life : the Social Construction of Scientific Facts, Los Angeles/Londres, Sage
[21]Laville, A., Gaudart, C., Pueyo, V. (2004). Vieillissement et travail. In E. Brangier, A. Lancry, C. Louche (Eds.). Les dimensions humaines du travail: Théories et pratiques de la psychologie du travail et des organisations. Nancy: Presses Universitaires de Nancy. 559-589.

[22]Le Masson P., Weil B., and Hatchuel A. (2006). Les processus d'innovation. Conception innovante et croissance des entreprises, Hermès - Lavoisier, Paris.

[23] Miettinen, R. 1998. Object construction and networks in research work: The case of research on cellulose degrading enzymes. Social Studies of Science Vol 38, 423-463.

[24] Milton J.P. and T. Farvar (eds) (1972), The careless technology - Ecology and international development, New-York, The Natural History Press.

[25] Molinié, A-F., Pueyo, V. (sous presse). Vie de travail et risques pour la santé. In Gaudart, C., Molinié, A-F., Pueyo, V. (Eds). La vie professionnelle -âge, expérience et santé à l'épreuve des conditions de travail. Toulouse : Octarès.

[26]Perrin, J. (1983). Les transferts de technologie. Editions La découverte, Collection repéres.

[27] Rabardel P. (1985). Les hommes et les technologies. Approche cognitive des instruments contemporains. Paris : Armand Colin.

[28] Rostow W. (1963), Les étapes de la croissance économique. Paris, Seuil, (édition originale, 1952).

[29] Schön, D. (1983). The reflective practitioner. How professionals think in action. Basic Book, Harper Collins Publisher, USA

[30] Sen, A. (2003). L'économie est une science morale. La découverte. Coll. Essais. Paris.

[31] Staudenmaier J. M. (1985). Technology's Storytellers. Cambridge, Massachusets: MIT Press.

[32] Suchman L., 1987. Plans and situated actions. Cambridge : Cambridge University Press

[33] Vicente, K. J. (1999). Cognitive work analysis: toward safe productive and healthy computer-based works.

[34] Wisner, A. (1985). Quand voyagent les usines. Essai d'anthropologie. Paris 